\title{
Detection of Mycobacterium avium subsp. paratuberculosis in asymptomatic bovines by I 5900 Polymerase Chain Reaction
}

\author{
Remya Raveendran, Priya P.M.*, Koshy J ohn, Krishnan Nair G, Vijayakumar K \\ College of Veterinary and Animal Sciences, \\ Thrissur, Kerala, India. \\ * Corresponding author email: priyamelepat@rediffmail.com \\ Published online at www. veterinaryworld.org on 25-03-2011
} \begin{abstract}
early diagnosis of bovine paratuberculosis.
Keywords: Paratuberculosis, MAP, IS900 PCR

\section{Introduction}

Paratuberculosis or Johne's disease (JD) is a chronic intestinal infection of several species of ruminants and is caused by Mycobacterium avium subsp. paratuberculosis (MAP). It is prevalent worldwide and cause substantial economic losses to the farming industry (Clarke, 1997). Since the disease is often subclinical, under - reporting is suspected eventhough the disease is notifiable in numerous countries. So early diagnosis of infected cattle is essential for controlling the spread of infection and eradication depends on detection and culling of infected animals as early as possible. No systematic study has been carried out on asymptomatic bovines in Kerala. Hence, the aim of this study was to determine whether IS900 PCR could be used for the detection of MAP from faecal samples of asymptomatic bovines.
\end{abstract}

Abstract

Faecal samples were collected from 58 asymptomatic bovines and after DNA extraction IS900 Polymerase Chain Reaction (IS900 PCR) was performed to detect Mycobacterium avium subsp. paratuberculosis (MAP). Ten samples (17.24\%) were positive for MAP. The results indicated that the IS900 PCR assay can be used for the

\section{Materials and Methods}

Faecal Samples - Faecal samples from 58 bovines were collected from University Livestock Farm (ULF), Mannuthy, Livestock Research Station (LRS), Thiruvazhamkunnu, Cattle Breeding Farm (CBF), Thumburmuzhy and one private farm in Thrissur. The animals were apparently normal with no clinical signs of JD at the time of collection. The samples were stored at $-20^{\circ} \mathrm{C}$.

DNA isolation - Deoxyribonucleic acid was isolated from faecal samples as per Braunstein et al. (2002) with some modifications. Two to three grams of faecal sample was mixed with $10 \mathrm{ml}$ of sterile triple distilled water in a mortar and pestle. It was then sieved into a test tube and the suspension were kept undisturbed overnight. Next day morning, supernatant was collected, centrifuged at $2000 \mathrm{rpm}$ for five minutes. The sediment was resuspended in one $\mathrm{ml}$ of Glucose Tris EDTA (GTE) solution and centrifuged for 10 minutes at $12,000 \mathrm{rpm}$. The pellet was resuspended in $450 \mu \mathrm{l}$ GTE, into which the following reagents were added one after the other and gently mixed after each addition. Fifty microlitre $(10 \mathrm{mg} / \mathrm{ml})$ of lysozyme, incubated overnight at $37{ }^{\circ} \mathrm{C} ; 100 \mu \mathrm{l}$ of 10 per cent SDS, $50 \mu \mathrm{l}(10 \mathrm{mg} / \mathrm{ml})$ of Proteinase K, incubated at $55^{\circ} \mathrm{C}$ for $20-40$ minutes; $200 \mu \mathrm{l}$ of $5 \mathrm{M}$ sodium chloride, $160 \mu \mathrm{l}$ of Cetyl Trimethyl Ammonium Bromide (CTAB), incubated at $65^{\circ} \mathrm{C}$ for 10 minutes and an equal volume of chloroform: isoamyl alcohol (24:1), centrifuged for 5 minutes at 12,000 rpm. Aqueous layer was collected and repeated the extraction with equal volume of chloroform: isoamyl alcohol mixture till the aqueous phase was clear. To $800 \mu$ l of clear aqueous layer, $560 \mu \mathrm{l}$ of 2-propanol was added and mixed gently by inversion until the DNA had precipitated out of solution. After centrifugation for 10 minutes at 12,000 rpm, supernatant was removed and washed the pellet with 70 per cent (v/v) ethanol and air dried. The DNA in the form of pellet was dissolved by adding thirty microlitre of Tris-EDTA buffer and stored at $-20{ }^{\circ} \mathrm{C}$ till used. Positive control DNA was obtained from Department of Animal Biotechnology, Madras Veterinary College, Chennai.

IS900 Polymerase Chain Reaction - PCR was performed with primer p11 and p36 (Halldorsdottir et al., 2002). The sequence of the forward primer $\mathrm{P} 36$ is 


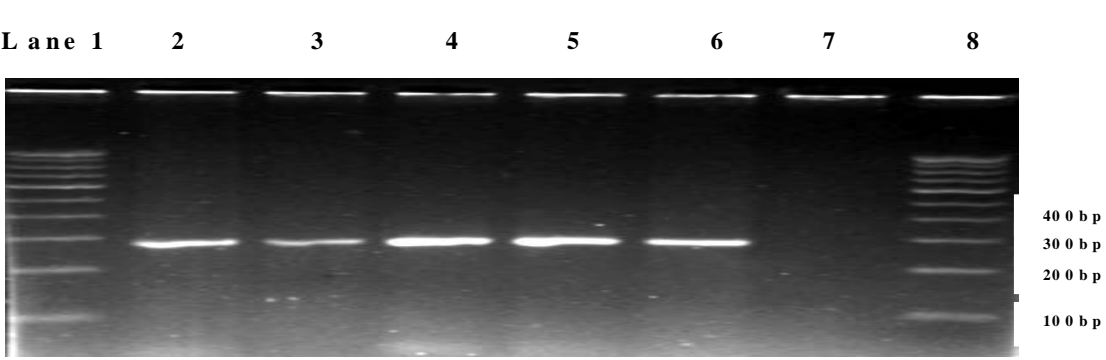

Fig. A garose gel electrophoresis of the PCR amplified product (279 b p) of IS 900 gen e of M A P

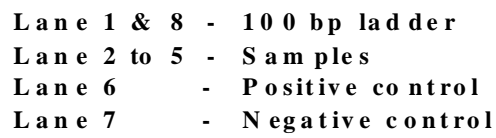

5'- GGCCGTCGCTTAGGCTTCGA-3' and that of the reverse primer P11 is 5'-CGTCGTTAATAACCATGCAG$3^{\prime}$. The $50 \mu \mathrm{l}$ reaction mixture comprised $25 \mu \mathrm{l}$ red dye master mix (Genei), $2 \mu$ l of each oligonucleotide primer and $5 \mu \mathrm{l}$ of DNA. The amplification consisted of an initial denaturation at $94{ }^{\circ} \mathrm{C}$ for 3 minutes, followed by 35 cycles of denaturation at $94{ }^{\circ} \mathrm{C}$ for 1 minute, primer annealing at $55{ }^{\circ} \mathrm{C}$ for 1 minute and extension at $72{ }^{\circ} \mathrm{C}$ for 1 minute. Positive and negative controls were kept for amplification along with the samples. The PCR products were analyzed by electrophoresis on 2 per cent agarose gel (Genei) in $1 \mathrm{x}$ TBE buffer. Then the gels were visualized by UV light transilluminator and the images were documented in a gel documentation system.

\section{Results and Discussion}

The positive control and positive samples gave an amplicon of $279 \mathrm{bp}$ size (Fig), but the negative control did not reveal any amplification. Ten samples (17.24 per cent) were positive out of the 58 samples. Among 15 samples tested from ULF, Mannuthy, 3 samples (20 per cent) were found positive. Out of 15 samples of LRS, Thiruvazhamkunnu, 3 (20 per cent) were positive. From CBF, Thumburmuzhy, 3 (18.75 per cent) were positive among 16 samples. Out of the 12 samples from a private farm in Thrissur, 1 (8.33 per cent) was found positive.

Eradication of paratuberculosis is hampered by the lack of accurate and sensitive diagnostic methods. The sub clinically infected animals are difficult to identify by faecal culture as the shedding of MAP vary with the stage of infection (Chiodini et al., 1984). Polymerase Chain Reaction is a rapid and reliable method for detecting paratuberculosis and can be used to identify samples that are culture negative and can detect fentogram amount of DNA(Huntley et al., 2005). Insertion sequence, IS900 was discovered by Collins et al. (1989) and the introduction of IS900 PCR has reduced the time and labor required for the MAP diagnosis.

\section{Acknowledgement}

The authors are thankful to the Dean, College of Veterinary and Animal Sciences, Mannuthy for providing requisite facilities for conducting the research work.

\section{References}

1. Braunstein, M., Bardarov, S.S. and Jacobs, Jr. W. R. (2002). Genetic methods for deciphering virulence determinants of Mycobacterium tuberculosis. Methods in Enzymology. 358: 67-99.

2. Chiodini, R. J., Kruininjen, H. J. and Merkal, R. S. (1984) Ruminant paratuberculosis (Johne's disease): the current status and future prospects. Cornell Vet. 74: 218-262.

3. Clarke C.J. (1997). The pathology and pathogenesis of paratuberculosis in ruminants and other species. J.Comp.Path. 116:217-261.

4. Collins, D.M., Gabric, D.M., and Delisle, G.W. (1989) Identification of a repetitive DNA sequence specific to Mycobacterium paratuberculosis. FEMS Microbiol. Lett. 60:175-178.

5. Deb. R. and Goswami, P.P. (2008). Molecular Biology: A Field of Great Contribution in Paratuberculosis Research Veterinary World, 1(5):157-158.

6. Halldorsdottir, S., et.al. (2002). Detection of Mycobacterium avium subsp. paratuberculosis by buoyant density centrifugation, sequence capture PCR and dot blot hybridization. Vet Microbiol. 87: 327-340.

7. Huntley, J.F.J., Whitlock, R.H., Bannantine, J.P. and Stabel, J.R. (2005). Comparison of diagnostic detection methods for Mycobacterium avium subsp. paratuberculosis in North American bison. Vet. Pathol. 42: 42-51.

$* * * * * * * *$ 